\title{
Examine the Feasibility of IT Investment: Identification of the Intangible Benefit Variable in Local Government
}

\author{
Fathiya Hasyifah Sibarani, Tony Dwi Susanto
}

\begin{abstract}
Information Technology (IT) has been an essential element that inseparable from the business, so it needs to invest in IT. Local Government is one of the institutions that implement IT investment. The purposes of investment in IT devices are to achieve business processes and improve efficiency and effectiveness of performance in Local Government. Company and Local Government have differences in IT investment because Local Government has its uniqueness. One of the uniqueness is Local Government does not familiar with Return on Investment (ROI) in project investment. Therefore, it needs a model that can be a basis for evaluating the feasibility of IT investment, specifically in Local Government. Thus, the management of IT investment is more directed and as needed. This research aims to identify the variables of Intangible benefit that can be used to evaluate the feasibility of IT investment in Indonesian Local Government. Based on the results of the identification of the variables, then authors made a proposed conceptual model that can be used as a reference to evaluate the feasibility of IT investment from a non-financial approach in Indonesian Local Government.
\end{abstract}

Keywords: Feasibility Evaluation, Information Technology Investment, Intangible Benefit, Local Government.

\section{INTRODUCTION}

In this digital era, everything that is traditional and manual slowly turning to use information technology (IT). IT has become a firm's crucial component that unavoidable and something that can be obtained from a sustainable competitive advantage [1]. Many companies and governments are competing to use IT to improve performance and productivity. IT is a set of tools that help work with information and carry out tasks related to information processing [2]. IT has a strategic role in organizations to take benefit of increased business performance and productivity. Organizations are encouraged to invest in IT because IT creates service innovation and efficiency, increases market share, and the capability of organizations to improve business processes [3]. Therefore, to get the benefits of IT, companies and governments must invest in IT.

Revised Manuscript Received on January 10, 2020.

* Correspondence Author

Fathiya Hasyifah Sibarani*, Department of Information Systems, Institu Teknologi Sepuluh Nopember, Surabaya, Indonesia. Email: tyafhs@gmail.com

Tony Dwi Susanto, Department of Information Systems, Institut Teknologi Sepuluh Nopember, Surabaya, Indonesia. Email: tonydwisusanto@is.its.ac.id
IT investment is a decision of investment to allocate all resources to a Management Information System (MIS), such as human and money [4]. IT investment is the total life cycle cost of the entire or part of the projects that involve IT, include operational cost after the projects run (post-project operating cost) of the system implemented [5].

There are several methods to evaluate the IT investments, namely Return on Investment (ROI), Cost Benefit Analysis (CBA), Multi Objective, Multi Criteria Methods (MOMC), Boundary Values (BV), Return on Management (ROM), Information Economics (IE), Critical Success Factors (CSF), Value Analysis (VA), dan Experimental Methods (EM) [6].

According to [7], Information Economics (IE) is a set of methods to calculate the costs and benefits of applying IT. IE was developed by the Cost Benefit Analysis (CBA) method. This method can help a company overcome the problems in the company's strategy and help the company to decide on the feasibility of IT investment.

According to [6], Marilyn Parker, Robert Benson, and Trainor is IT practitioners who made a breakthrough through their "Information Economics" theory as one of the ways rated "accurate" until now related to the process of analyzing the costs and benefits of implementing IT.

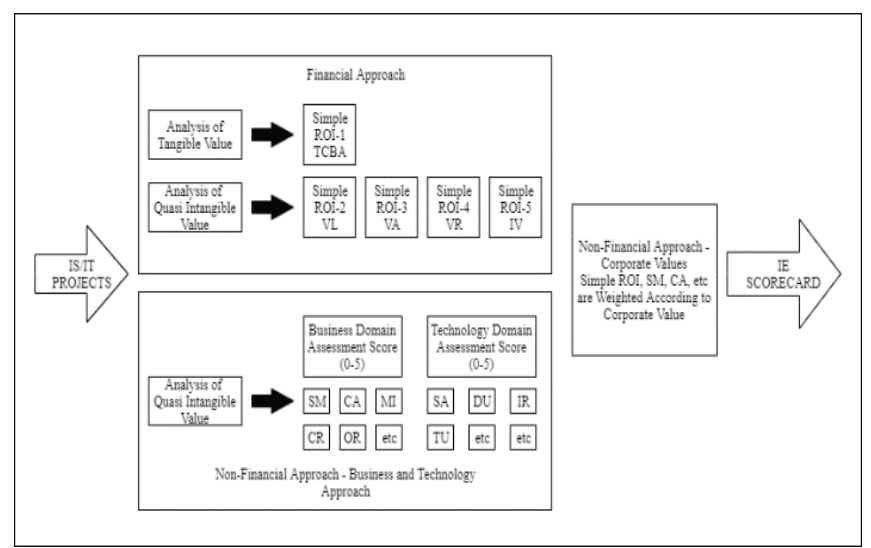

Fig. 1. Information Economics (IE) Framework

Fig. 1 showed that the IE method could be used to assess investment that produces IT investment score and economic value. IE has two aspects, namely, Financial and Non-Financial. The Financial aspect consists of Tangible benefit and Quasi Tangible benefit, and then the Non-Financial aspect consists of Business Domain and Technology Domain [8].

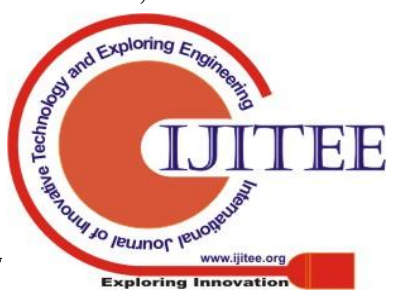




\section{A. Intangible Benefit}

Intangible benefit is a problem for financial measurements. Some literature claimed that all of the financial measurements are failed to capture intangible benefits be produced by the investment [9].

This intangible benefit approach has a positive impact on the company but affects the company's revenue or profit indirectly. According to the Information Economics method, the feasibility of investment from non-financial aspects can be seen from two domains, namely Business Domain and Technology Domain [7].

\section{- Business Domain}

Business Domain has several components, namely:

1. Strategic Match (SM): Finding out the extent of investment aligned with the strategic business goals.

2. Competitive Advantage (CA): Finding out the extent of investment contributes to the improved market position.

3. Management Information (MI): Finding out the extent of investment informs management of the main firm activities.

4. Competitive Response (CR): Finding out the extent of not investing can imply risk and on time investment will contribute to strategic advantage.

5. Organizational Risk (OR): Finding out the extent of required new competencies.

\section{- Technology Domain}

Technology Domain has several components, namely:

1. Strategic IS Architecture (SA): How is the suitability level of the project with the overall IS / IT planning.

2. Definitional Uncertainty (DU): How much uncertainty is due to changes in the target.

3. Technical Uncertainty (TU): How much the project relies on expertise, hardware, software, and systems.

4. Infrastructure Risk (IR): How important is a non-project investment to accommodate this project.

To find out the impact and benefit of IT investment, the evaluation must be carried out. Evaluation is a crucial component of decision making. The skill used by an organization to manage the decision-making process will be the main factor in the final value, effectiveness, and relevance of its evaluation exercises [10]. IS/IT investment evaluation that has been applied will influence the feasibility of investment financially and non-financially using Information Economics (IE) approach [11]. IE method focuses on benefits and costs analysis associated with business performance value. IE that evaluates the feasibility based on non-financial will show the quantitative perspective and improve business outcomes [11]. One of the excellences of the IE method is the ability to consider half of tangible benefit and intangible benefit that often ignored by investors or management [8].

This research focuses on Intangible benefit in Local Government for several reasons, namely Government does not familiar with the Return on Investment (ROI) in project investment, basically IT projects are implemented to meet the strategic direction of the institution, Cost Benefit Analysis (CBA) approach needs to be simplified and adjusted to the needs of Government by focusing on non-financial analysis so that financial analysis is eliminated because in the Government concerned is the issue of budget availability [12]. In organizations of the public sector, there is more emphasis on the fulfillment of political goals and less on the value of economics that IT conveys internally. One of the political goals is better collaboration between government entities that are loosely coupled and increased citizen access to public services [13].

This research aims to identify the Intangible benefit variables related to Business Domain and Technology Domain. The result of this research is the identification of the Intangible benefit variables made as a proposed conceptual model that can be used as a reference to evaluate the feasibility of IT investment from a non-financial approach in Indonesian Local Government.

\section{METHODS}

This research developed the Information Economics method, especially on Intangible benefits then adjust it to the existing conditions in Local Government.

\section{A. Data Collection}

Data collection conducted by collecting Intangible benefit variables from previous studies. Previous studies are obtained from journal or publisher databases. The keywords to find the previous studies related to this research by using IT investment Model and Indonesian Government IT investment. Then the data collected was obtained from the IEEE Xplore database journal [14] [15] [3] and investment module in Government by the Ministry of Communication and Information Technology [12].

\section{B. Data Mapping}

Data mapping conducted after the previous studies have been obtained and analyzed. After the variables are obtained, a mapping of the variables is carried out by grouping the variables into the Business Domain and Domain Technology based on Information Economics domain [7].

\section{RESULT AND DISCUSSION}

The literature study conducted to find out the variables of Business Domain and Technology Domain to Evaluating the feasibility of IT investment in Local Government.

\section{A. Analysis of Intangible Benefit Variable}

In this stage, there are so many variables collected from the previous research, as shown in Table- I. According to Table- I, it can be seen only several previous studies have discussed the IT investment model in Indonesian Local Government. According to [7], in Intangible benefit, there are two domains, namely Business Domain and Technology Domain. The variables of Business Domain are Strategic Match, Competitive Advantage, Management Information, Competitive Response, and Project Organizational Risk. For Technology Domain's variables are Strategic IS Architecture, Definitional Uncertainty, Technical Uncertainty, and Infrastructure Risk. 
According to [12], the variables obtained are divided into two domains, namely Business Domain and Technology Domain.

This Intangible benefit is obtained from the development of the Information Economics method [7], which focuses on Local Government. The variables of Business Domain are Strategic Alignment, Management Information, Organizational Risk, Customer Response, and Compliance Response. The variables of Technology Domain are IS Architecture, IT Infrastructure Architecture, Technical Availability, and Definitional Certainty.

According to [15], there are seven variables that are influencing IT investment in Government Sector, namely Financial, Organizational, Political and Policy, Technological, IT Risk, IT Human Resources, and Social. The most significant variables are Financial variable and IT Human Resources variable. The non-financial or the intangible benefit variable is IT Human Resources.

According to [3], there are seven variables that are influencing Social and Political factors in Government IT Investment, namely Social, Politic, Technology, Financial, Organization, Human Resource, and Strategy variable. The variable that must be considered in IT investment is Politic, Technology, and Strategy.

Table- I: Analysis of Intangible Benefit Variable

\begin{tabular}{|c|c|c|}
\hline No. & Variable & Reference \\
\hline 1. & Strategic Match & \multirow{9}{*}{ [7] } \\
\hline 2. & Competitive Advantage & \\
\hline 3. & Management Information & \\
\hline 4. & Competitive Response & \\
\hline 5. & Project Organizational Risk & \\
\hline 6. & Strategic IS Architecture & \\
\hline 7. & Definitional Uncertainty & \\
\hline 8. & Technical Uncertainty & \\
\hline 9. & Infrastructure Risk & \\
\hline 10. & Strategic Alignment & \multirow{9}{*}{ [12] } \\
\hline 11. & Management Information & \\
\hline 12. & Organizational Risk & \\
\hline 13. & Customer Response & \\
\hline 14. & Compliance Response & \\
\hline 15. & IS Architecture & \\
\hline 16. & IT Infrastructure Architecture & \\
\hline 17. & Technical Availability & \\
\hline 18. & Definitional Certainty & \\
\hline 19. & Financial & \multirow{7}{*}[15]{} \\
\hline 20. & Organizational & \\
\hline 21. & Political and Policy & \\
\hline 22. & Technological & \\
\hline 23. & IT Risk & \\
\hline 24. & IT Human Resource & \\
\hline 25. & Social & \\
\hline 26. & Social & \multirow{6}{*}[3]{} \\
\hline 27. & Politic & \\
\hline 28. & Technology & \\
\hline 29. & Financial & \\
\hline 30. & Organization & \\
\hline 31. & Human Resource & \\
\hline
\end{tabular}

\section{B. Definition of Variable}

After obtained several variables from previous studies, the variables are selected and adjusted to the object of this study. After the adjustment is made, then the variable mapping is done to group the variables into two domains. For details on each variable can be seen in Table- II.

Table- II: Variable Definition

\begin{tabular}{|c|c|c|c|}
\hline Domain & Variable & Definition & Reference \\
\hline \multirow{8}{*}{ Business } & $\begin{array}{c}\text { Strategic } \\
\text { Alignment }\end{array}$ & $\begin{array}{l}\text { Aligning the IT with strategic } \\
\text { business objectives }\end{array}$ & $\begin{array}{c}\text { [7] [12] } \\
{[3]}\end{array}$ \\
\hline & $\begin{array}{l}\text { Competitive } \\
\text { Advantage }\end{array}$ & $\begin{array}{l}\text { IT can increase competition } \\
\text { with other Local Government }\end{array}$ & [7] \\
\hline & $\begin{array}{l}\text { Management } \\
\text { Information }\end{array}$ & $\begin{array}{l}\text { IT contributes to decision } \\
\text { making for better Local } \\
\text { Government performance }\end{array}$ & [7] [12] \\
\hline & $\begin{array}{l}\text { Competitive } \\
\text { Response }\end{array}$ & $\begin{array}{l}\text { Measuring the benefits of IT } \\
\text { (the higher the benefit, then } \\
\text { the purchase of IT cannot be } \\
\text { postponed) }\end{array}$ & [7] \\
\hline & $\begin{array}{l}\text { Customer } \\
\text { Response }\end{array}$ & $\begin{array}{l}\text { IT can respond to citizen } \\
\text { service needs }\end{array}$ & [12] [3] \\
\hline & $\begin{array}{l}\text { Compliance } \\
\text { Response }\end{array}$ & $\begin{array}{l}\text { Aligning the IT to laws } \\
\text { related to IT investment }\end{array}$ & {$[12]$} \\
\hline & $\begin{array}{l}\text { IT Human } \\
\text { Resource }\end{array}$ & $\begin{array}{l}\text { Comprehension of Local } \\
\text { Government employees on } \\
\text { IT }\end{array}$ & [15] [3] \\
\hline & $\begin{array}{l}\text { Organizationa } \\
\quad \text { l Risk }\end{array}$ & $\begin{array}{l}\text { The readiness of Local } \\
\text { Government employees for } \\
\text { changes that will occur with } \\
\text { the implementation of IT }\end{array}$ & [7] [12] \\
\hline \multirow{4}{*}{$\begin{array}{c}\text { Technolog } \\
y\end{array}$} & IS Architecture & $\begin{array}{l}\text { Aligning the IT with the } \\
\text { Local Government IS } \\
\text { architecture blueprint }\end{array}$ & [12] \\
\hline & $\begin{array}{c}\text { Definitional } \\
\text { Certainty }\end{array}$ & $\begin{array}{l}\text { IT needs are clearly defined } \\
\text { and agreed upon }\end{array}$ & {$[12]$} \\
\hline & $\begin{array}{l}\text { Technical } \\
\text { Availability }\end{array}$ & $\begin{array}{l}\text { The readiness of Local } \\
\text { Government or Agency for } \\
\text { IT to be purchased (readiness } \\
\text { in terms of experts, software, } \\
\text { and infrastructure) }\end{array}$ & {$[12]$} \\
\hline & $\begin{array}{l}\text { Infrastructure } \\
\text { Risk }\end{array}$ & $\begin{array}{l}\text { Identify things that support } \\
\text { the success of IT } \\
\text { implementation }\end{array}$ & [7] \\
\hline
\end{tabular}

\section{CONCLUSION AND SUGGESTION}

Today many companies and Local Governments invest in IT to improve their performance. When investing in IT, an evaluation must be carried out to determine whether the investment is feasible or not feasible. There are several methods for evaluating the feasibility of IT investment. This research focused on the Information Economics method, and the method was developed to suit the conditions in Local Government. Based on [12], this research is focused on the non-financial approach or Intangible benefit. The purpose of this research is to identify the Intangible benefit variables that can be used to evaluating IT investment feasibility in Local Government. From the variables that have been obtained, the authors proposed a conceptual model, as seen in Fig. 2.

$$
\text { \& Sciences Publication Exploring Innovation }
$$




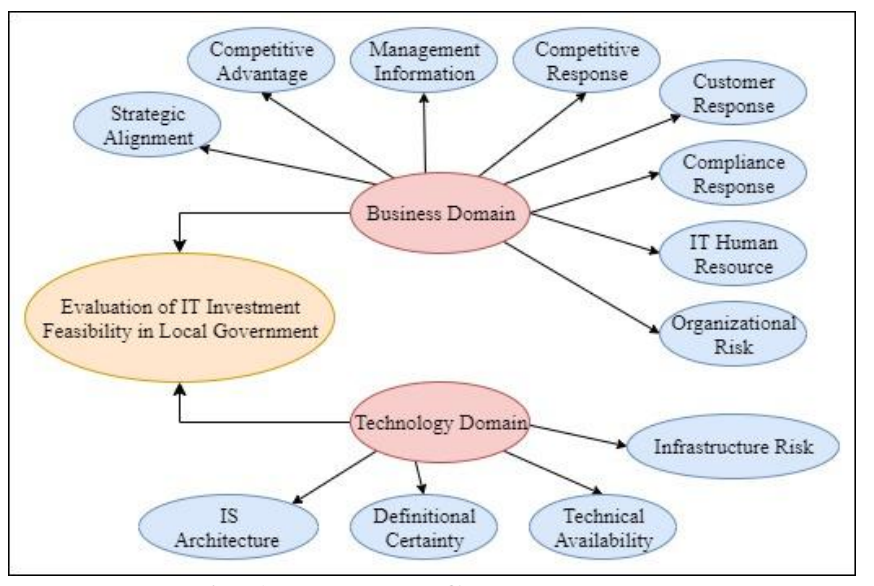

Fig. 2. Proposed Conceptual Model

The method used to identify the Intangible benefit variable was from previous research that has developed an IT investment model in Indonesian Local Government. After obtaining these variables, an analysis was carried out so that mapping can be done to the Business Domain and Technology Domain. The obtained variables have been adapted to Local Government conditions and developed the Information Economics model. Business Domain has eight variables, namely Strategic Alignment, Competitive Advantage, Management Information, Competitive Response, Customer Response, Compliance Response, IT Human Resource, and Organizational Risk. Technology Domain has four variables, namely IS Architecture, Definitional Certainty, Technical Availability, and Infrastructure Risk.

The result of this research is a proposed conceptual model can be used to evaluating IT investment feasibility in Local Government. These variables have been adjusted to the object of this research. For further research, the Intangible benefit variable for Local Government can be developed so the variable can be more accurate and useful.

\section{REFERENCES}

1. G. Y. Koi-Akrofi, "Justification for IT Investments: Evaluation Methods, Frameworks, and Models," Texila International Journal of Management, vol. 3, no. 2, pp. 1-11, 2017.

2. S. Haag dan P. Keen, Information Technology: Tomorrow's Advantage Today, McGraw-Hill College, 1996.

3. H. E. Sarwadhamana dan B. Pharmasetiawan, "Analysis of the Influence of Social and Political Factors Towards the Success of the Government IT Investment," IEEE, pp. 1-6, 2018.

4. M. J. Schniederjans, J. L. Hamaker dan A. M. Schniederjans, Information Technology Investment: Decision-Making Methodology (2nd Edition), 2nd penyunt., Singapore: World Scientific Publishing Company, 2010.

5. E. W. Fitzpatrick, Planning and Implementing IT Portfolio Management: Maximizing the Return on Information Technology Investments, IT Economics Corporation, 2005.

6. R. E. Indrajit, Benefits and Cost Analysis Model of Information Technology Investment, APTIKOM, 2002. (in Indonesian)

7. M. M. Parker, R. J. Benson dan H. Trainor, Information Economics: Linking Business Performance to Information Technology, London: Prentice Hall, 1988.

8. B. K. Kristanto dan F. Samopa, "Feasibility Study of Investment on Academic Information Systems STIKES Pemkabjombang Based on Information Economics," International Journal of Research in Engineering and Technology (IJRET), vol. 06, no. 01, pp. 104-108, 2017.

9. J. Ballantine dan S. Stray, "Financial appraisal and the IS/IT investment decision making process," Journal of Information Technology, vol. 13, pp. 3-14, 1998.
10. A. Brown, "IS Evaluation in Practice," The Electronic Journal Information Systems Evaluation (EJISE), vol. 8, no. 3, pp. 169-178, 2005.

11. E. Novianti dan A. N. Fajar, "Information Technology Investment Analysis of Hospitality Using Information Economics Approach," TELKOMNIKA, Vol. \%1 dari \%217, No. 2, pp. 609-614, 2019.

12. Kemenkominfo, Management of Information Technology Investment in Government Sector, Module, Ministry of Communication and Informatics Republic of Indonesia, 2013. (in Indonesian)

13. A. Chircu dan D. Lee, "Understanding IT Investments in the Public Sector: The Case of E-Government," Americas Conference on Information Systems (AMCIS) 2003 Proceedings. Paper 99, pp. 792-800, 2003.

14. K. R. Ningsih, J. Sembiring, A. A. Arman dan A. I. Wuryandari, "Developing IT Investment Management Framework of Government Institution," IEEE, pp. 237-242, 2013.

15. E. Susilawati dan K. Surendro, "A Model Design of Information Technology Investment for The Government Sector," International Conference on Information Technology Systems and Innovation (ICITSI), pp. 32-37, 2017.

\section{AUTHORS PROFILE}

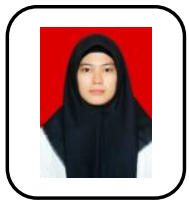

Fathiya Hasyifah Sibarani, is a Master student in Department of Information Systems, Institut Teknologi Sepuluh Nopember, Indonesia. She has completed her Bachelor of Information System in the year 2017 from Universitas Islam Negeri Sultan Syarif Kasim Riau, Indonesia

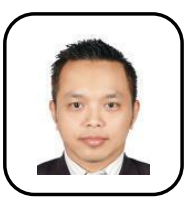

Tony Dwi Susanto, is a lecturer in Department of Information Systems, Institut Teknologi Sepuluh Nopember, Indonesia. He has completed his Ph.D in Computer Science in the year 2012 from Flinders University of South Australia. He has numerous research publications in national and international journal and conference proceeding, and published books. His research interests are e-Government, IT Governance, Technology Adoption, Information Systems, and IT Service Management. He is a President of Association for Information Systems - Indonesia Chapter (AISINDO), and CEO of PT. Tatacipta Teknologi Indonesia (TATI). He has ITIL, COBIT, and TOGAF certificates. 